Article

\title{
Germinated Riceberry Rice Enhanced Protocatechuic Acid and Vanillic Acid to Suppress Melanogenesis through Cellular Oxidant-Related Tyrosinase Activity in B16 Cells
}

\author{
Teerapat Rodboon ${ }^{1}$, Seiji Okada ${ }^{2}$ (I) and Prasit Suwannalert ${ }^{1, *}$ \\ 1 Department of Pathobiology, Faculty of Science, Mahidol University, Bangkok 10400, Thailand; \\ rteerapat@gmail.com \\ 2 Division of Hematopoiesis, Joint Research Center for Human Retrovirus Infection \& Graduate School of \\ Medical Sciences, Kumamoto University, Kumamoto 860-0811, Japan; okadas@kumamoto-u.ac.jp \\ * Correspondence: prasit.suw@mahidol.ac.th
}

Received: 17 February 2020; Accepted: 10 March 2020; Published: 19 March 2020

\begin{abstract}
The anti-melanogenic bioactivities of phytophenolic compounds have been well recognized. Riceberry rice contains a rich source of phenolic compounds that act as melanin inhibitors through their antioxidant and anti-tyrosinase properties. Germination has been shown to be an effective process to improve targeted phenolic compounds. In this study, germinated riceberry rice extract was tested for antioxidant activity. Total phenolic content was determined while the tyrosinase inhibitory effect was screened by the in vitro mushroom tyrosinase assay. Cytotoxicity of germinated riceberry rice extract was investigated in B16 cells before evaluating its activities on cellular tyrosinase, melanogenesis, melanin excretion, morphological appearance, and cellular oxidants. Germinated riceberry rice extract showed increased potency of antioxidants and was also twice as effective for mushroom tyrosinase inhibition when compared with ungerminated riceberry rice extract. In B16 cells, the extract inhibited cellular tyrosinase, melanogenesis, and cellular oxidants in a dose-dependent manner when compared with untreated cells. Germinated riceberry rice extract also displayed an effect on B16 cells morphology by reducing the number of melanin- containing cells and their dendriticity. Additionally, the germination of riceberry rice dominantly enhanced two phenolic acids, protocatechuic acid and vanillic acid, which have the potential for antioxidant-associated hyperpigmentation control. Thus, the restricted germination of riceberry rice tended to promote protocatechuic acid and vanillic acid, which dominantly displayed antioxidants and tyrosinase-related melanogenic inhibition.
\end{abstract}

Keywords: melanogenesis; riceberry rice; antioxidants; tyrosinase; oxidative stress

\section{Introduction}

Hyperpigmentation disorder results from the overproduction of melanin pigments and has been identified as a dermatological problem that can be psychologically devastating to patients [1]. A wide variety of chemical agents have been used extensively for hyperpigmentation control. Several reports have examined their adverse effects and toxicity [2,3]. In this study, novel effective natural products for hyperpigmentation treatment were elucidated. Several phenolic acids have been identified as having anti-melanogenic properties via the inhibition of tyrosinase, a key enzyme for melanogenesis [4-7]. In addition, the antioxidant activity of natural compounds was also considered for the protection and treatment of hyperpigmentation [8,9].

Riceberry rice, a new breeding line of Thai black purple rice, has shown high levels of antioxidants and targeted phenolic compounds including ferulic acid, gallic acid, 4-hydroxybenzoic acid, vanillic 
acid, chlorogenic acid, syringic acid, p-coumaric acid, and ferulic acid [10,11] that act as tyrosinase inhibitors. Previously, a suitable germination process promoted both the quantitative and qualitative aspects of these valuable phenolic compounds [12-15]. In this study, riceberry rice was enhanced for anti-melanogenesis by the germination process. Germinated riceberry rice extract could be further developed as a novel agent for hyperpigmentation control.

\section{Materials and Methods}

\subsection{Rice Germination}

Riceberry rice was obtained from Phayao province, Thailand. A hundred grams of rice were soaked in reverse osmosis water, $\mathrm{pH} 7.2-7.4$ for $1 \mathrm{~h}$. Soaked riceberry rice was germinated in a polyethylene tray $(22 \times 22 \times 5 \mathrm{~cm})$ at room temperature in the dark for $6 \mathrm{~h}$. Subsequently, germinated riceberry rice was lyophilized and then ultracentrifugally powdered. The riceberry rice powder was then sieved through $345 \mu \mathrm{m}$ and stored at $-20{ }^{\circ} \mathrm{C}$ until extraction.

\subsection{Rice Sample Extraction}

Riceberry rice powder was extracted by using $80 \%$ ethanol in distilled water at a ratio of 1:4. The mixture was continuously shaken at $10 \mathrm{~g}, 25^{\circ} \mathrm{C}$ for $6 \mathrm{~h}$ under dark conditions. The supernatant was harvested by centrifugation at $800 \times g$ for $15 \mathrm{~min}$ and sterilized by filtration through Whatman Filter Paper No.1. The sample was dried using a rotary evaporator (Marshall Scientific, Hampton, VA, USA) at $40{ }^{\circ} \mathrm{C}, 200 \mathrm{~mm} / \mathrm{Hg}$, and dehydrated by a lyophilizer (Thermo Fisher Scientific, Waltham, MA, USA). Dried stock samples were stored at $-20^{\circ} \mathrm{C}$ until used in the experiments.

\subsection{In Vitro Antioxidant Activities}

\subsubsection{2,2'-Azino-bis(3-Ethylbenzothiazoline-6-Sulfonic Acid) (ABTS) Radical Scavenging Assay}

The ABTS radical scavenging activity of the sample was investigated by using a modified method from a previous study [16]. Briefly, the ABTS• stock solution $(7 \mathrm{mM})$ was prepared by reacting ABTS (Sigma-Aldrich, Singapore) with $2.45 \mathrm{mM}$ potassium persulfate (Sigma-Aldrich, Singapore) solution at room temperature under dark conditions for $12 \mathrm{~h}$. A working ABTS• solution was then prepared by diluting the stock solution with distilled water. The working reagent was adjusted to obtain an absorbance of $0.80 \pm 0.05$ at $734 \mathrm{~nm}$. Then, $200 \mu \mathrm{L}$ of sample or Trolox (Sigma-Aldrich, Singapore) were reacted with $1.8 \mathrm{~mL}$ of working ABTS• solution for $30 \mathrm{~min}$ before measuring at $734 \mathrm{~nm}$. The ABTS radical scavenging activity was calculated and compared with the Trolox standard curve. The result was expressed as mg Trolox equivalent/g sample.

\subsubsection{2,2 Diphenyl-1-Picrylhydrazyl (DPPH) Radical Scavenging Assay}

The DPPH radical scavenging activity of the sample was examined as previously mentioned [17]. Briefly, a working DPPH• solution $(6 \mu \mathrm{M})$ was freshly prepared by adjusting the absorbance of $2 \mathrm{mM}$ DPPH• (Sigma-Aldrich, Singapore) stock solution to $0.80 \pm 0.05$ at $517 \mathrm{~nm}$ by using methanol. Then, $200 \mu \mathrm{L}$ of sample at various concentrations or a serial dilution of L-ascorbic acid (VitC) (Sigma-Aldrich, Singapore) were reacted with $1.8 \mathrm{~mL}$ of working DPPH• solution for $30 \mathrm{~min}$ before measuring at $517 \mathrm{~nm}$. The DPPH radical scavenging activity was calculated and compared with the activity with the Vit $C$ standard curve. The result was expressed as $\mathrm{mg}$ Vit $C$ equivalent/g sample.

\subsubsection{Ferric Reducing Antioxidant Power (FRAP) Assay}

The FRAP assay is a method for determining the antioxidant activity of a sample to reduce $\mathrm{Fe}^{3+}$ to $\mathrm{Fe}^{2+}$. This assay was carried out according to a previous study [18]. Briefly, the FRAP reagent was freshly prepared by mixing $300 \mathrm{mM}$ acetate buffer with $10 \mathrm{mM}$ TPTZ (Sigma-Aldrich, Singapore) solution and $20 \mathrm{mM}$ ferric chloride (Sigma-Aldrich, Singapore) solution. Then, $180 \mu \mathrm{L}$ of FRAP reagent 
were reacted with $20 \mu \mathrm{L}$ of sample or $\mathrm{FeSO}_{4} \cdot 7 \mathrm{H}_{2} \mathrm{O}$ (Sigma-Aldrich, Singapore) for 30 min before measuring at $593 \mathrm{~nm}$. Ferric reducing activity was calculated and the activity compared with the $\mathrm{FeSO}_{4} \cdot 7 \mathrm{H}_{2} \mathrm{O}$ standard curve. The result was expressed as $\mathrm{M} \mathrm{FeSO}_{4} \cdot 7 \mathrm{H}_{2} \mathrm{O}$ equivalent/g sample.

\subsection{Total Phenolic Content}

The total phenolic content of the sample was determined by the Folin-Denis assay, as described previously [8]. Briefly, $20 \mu \mathrm{L}$ of sample or gallic acid (Sigma-Aldrich, Singapore) were mixed with $100 \mu \mathrm{L}$ of Folin-Denis reagent (Sigma-Aldrich, Singapore) and $1880 \mu \mathrm{L}$ of $7.5 \%$ aqueous sodium bicarbonate solution for $30 \mathrm{~min}$ at room temperature. The reaction was measured at $765 \mathrm{~nm}$. The total phenolic content was calculated and the activity compared with the gallic acid standard curve. The result was expressed as mg gallic acid equivalent/g sample.

\subsection{In Vitro Mushroom Tyrosinase Activity}

The inhibitory effect of the sample for tyrosinase inhibition was investigated by an in vitro mushroom tyrosinase activity assay modified from a previous study [19]. Briefly, $50 \mu \mathrm{L}$ of sample were pre-incubated with $100 \mu \mathrm{L}$ of phosphate buffered saline (PBS), pH 7.1, and $50 \mu \mathrm{L}$ of mushroom tyrosinase (Sigma-Aldrich, Singapore) at room temperature for $10 \mathrm{~min}$. The mixture was then incubated with $20 \mu \mathrm{L}$ of $1 \mathrm{mM}$ 3,4-dihydroxyphenylalanine (L-DOPA) (Sigma-Aldrich, Singapore) at $37^{\circ} \mathrm{C}$ for $30 \mathrm{~min}$. Dopachrome was measured at $492 \mathrm{~nm}$. The result was expressed as the necessary concentration to achieve $50 \%$ inhibition $\left(\mathrm{IC}_{50}\right)$.

\subsection{Cell Culture}

B16 cells (ATCC Number CRL-6475 ${ }^{\mathrm{TM}}$, VA, USA) were maintained in low glucose DMEM (Sigma-Aldrich, Singapore) supplemented with 10\% fetal bovine serum (Gibco Life Technologies, Massachusetts, MA, USA), 10 U/mL of penicillin (Gibco Life Technologies, Massachusetts, MA, USA), and $10 \mathrm{mg} / \mathrm{mL}$ of streptomycin (Gibco Life Technologies, Massachusetts, MA, USA) in a $37^{\circ} \mathrm{C}, 5 \% \mathrm{CO}_{2}$, and $95 \%$ humidified atmosphere.

\subsection{Cell Viability}

\subsubsection{MTT 3-(4,5-Dimethyl-2-yl)-2,5-Diphenyltetrazolium Bromide Assay}

The cytotoxicity of the sample on B16 cells was measured by using the MTT assay modified from a previous study [20]. Briefly, B16 cells were plated into 96 well plates at a density of $3 \times 10^{4}$ cells/well and then incubated for $24 \mathrm{~h}$. B16 cells were treated with the sample at various concentrations and incubated for $24 \mathrm{~h}$. Treated cells were then reacted with $1.2 \mathrm{mM}$ MTT (Sigma-Aldrich, Singapore) solution for $3 \mathrm{~h}$. The formazan crystal was then solubilized with absolute DMSO (Merck, Kenilworth, NJ, USA) and measured at $530 \mathrm{~nm}$. The result was expressed as the percentage of cell viability by comparing the mean \pm SD with untreated cells ( $100 \%$ of cell viability).

\subsubsection{Trypan Blue Viability Assay}

Cell viability was also determined by the trypan assay, based on a previous study [21]. Briefly, $3 \times 10^{4}$ of B16 cells were plated into 96 well plates and incubated for $24 \mathrm{~h}$. The cells were treated with the sample at various concentrations and further incubated for $24 \mathrm{~h}$. The cells were detached by trypsinization and stained by $0.1 \%$ trypan blue solution (Merck, Kenilworth, NJ, USA). The viable cells and dead cells were counted separately, and the percentage of viable cells was calculated by comparing the mean \pm SD with untreated cells ( $100 \%$ of cell viability).

\subsection{Melanin Content and Melanin Excretion}

Melanin content was determined as described previously [22]. Briefly, $1.0 \times 10^{5}$ of B16 cells were plated into 6 well plates and incubated for $24 \mathrm{~h}$. The cells were treated with non-toxic concentrations of 
the sample and incubated for $72 \mathrm{~h}$. Melanin excretion was optically determined in a culture medium at $405 \mathrm{~nm}$. Intracellular melanin content was detected in pellets by disruption with $1 \mathrm{~N} \mathrm{NaOH}$ solution at $80^{\circ} \mathrm{C}$ for $4 \mathrm{~h}$ and measured at $405 \mathrm{~nm}$. Ten micromolar hydroquinone (HQ) (Sigma-Aldrich, Singapore) was used as a positive control.

\subsection{Differentiation and Morphological Appearances of B16 Cells}

The effects of the samples on differentiated B16 cells and their morphological appearances were observed using a modified of Fontana-Masson staining method [23]. Briefly, $1.0 \times 10^{5}$ of B16 cells were plated into 6 well plates and incubated for $24 \mathrm{~h}$. Cells were treated with the sample at the indicated concentrations and further incubated for $72 \mathrm{~h}$. Fontana-Masson staining was conducted by using a Fontana-Masson Stain Kit (Bio-Optica, Milan, Italy) according to the manufacturer's instructions. The number of cells containing melanin was counted in a total of 1000 of B16 cells under a light microscope at 100× magnification. The morphological appearances of differentiated B16 cells were scored in a total of 100 differentiated B16 cells as $1+, 2+, 3+$, and $4+$, as presented Table 1.

Table 1. Differentiated B16 cells scoring system.

\begin{tabular}{llc}
\hline \multicolumn{1}{c}{ Criterion } & Score \\
\hline 1. & $\begin{array}{l}\text { Dendritic shape with a bipolar spindle, cell size at } 1-50 \mu \mathrm{m} \text {, pigmentation } \\
\text { lower than } 50 \% \text { of cytoplasmic area with a low distribution. }\end{array}$ & $1+$ \\
2. $\begin{array}{l}\text { Dendritic shape with a bipolar spindle, cell size at } 1-50 \mu \mathrm{m} \text {, pigmentation } \\
\text { equal to or more than } 50 \% \text { of cytoplasmic area with a higher distribution. }\end{array}$ & $2+$ \\
3. $\begin{array}{l}\text { Multi-polar spindle without tip branches, cell size larger than } 51 \mu \mathrm{m} . \\
\text { Pigmentation throughout the cytoplasmic area. }\end{array}$ & $3+$ \\
4. $\begin{array}{l}\text { Multi-polar spindle with numerous tip branches, cell size larger than } 51 \mu \mathrm{m} . \\
\text { Pigmentation densely packed throughout the cytoplasmic area. }\end{array}$ & $4+$ \\
\hline
\end{tabular}

\subsection{Cellular Tyrosinase Activity}

The effect of samples on cellular tyrosinase activity was determined using a method mentioned previously [24]. Briefly, B16 cells were plated into 6 well plates at a density of $1.0 \times 10^{5}$ cells $/ \mathrm{mL}$ and incubated for $24 \mathrm{~h}$. The cells were treated with the sample at non-toxic concentrations and incubated for $72 \mathrm{~h}$. Treated cells were solubilized with PBS, pH 7.1 containing 1\% Triton X-100 (Sigma-Aldrich, Singapore). The cell lysate was clarified by centrifugation at $15,000 \times g$ for 15 min to obtain the supernatant. Then, $50 \mu \mathrm{L}$ of supernatant were reacted with $50 \mu \mathrm{L}$ of $2 \mathrm{mM} \mathrm{L}-\mathrm{DOPA}$ at $37^{\circ} \mathrm{C}$ for $90 \mathrm{~min}$ before measuring the dopachrome product at a wavelength of $492 \mathrm{~nm}$. Ten micromolar hydroquinone (HQ) was used as a positive control.

\subsection{Cellular Oxidants}

Cellular oxidants of B16 cells were determined by using the dichloro-dihydro-fluorescein diacetate (DCFH-DA) method based on a previous study [6]. Briefly, B16 cells were plated into 96 well plates at a density of $3.0 \times 10^{4}$ cells/well and incubated for $24 \mathrm{~h}$. Cells were treated with non-toxic concentrations of the sample and incubated for $24 \mathrm{~h}$. The cells were washed with PBS, pH 7.4, and incubated with $10 \mu \mathrm{M}$ DCFH-DA (Merck, Kenilworth, NJ, USA) solution for $3 \mathrm{~h}$. The cellular oxidants were determined by fluorescence intensity at 485/535 nm. Twenty millimolar N-acetylcysteine (NAC) (Merck, Kenilworth, NJ, USA) was used as a positive control.

\subsection{High Performance Liquid Chromatography (HPLC)}

Phytophenolics in the samples were identified using an HPLC technique with slight modification [25]. Briefly, samples were eluted by absolute acetonitrile solution (A) and $0.1 \%$ trifluoroacetic acid solution in distilled water (B) under the gradient elution (Solvent A:Solvent B) at 5-9\%:95-91\%, 9\%:91\%, 9-11\%:91-89\%, and 11-50\%:89-50\% with respective time periods of 
0-5, 5-15, 15-22, and 22-25 min. The flow rate was controlled at $0.8 \mathrm{~mL} / \mathrm{min}$ under an $\mathrm{ACE}{ }^{\circledR} \mathrm{C} 18$ column (Advanced Chromatography Technologies, Aberdeen, Scotland) $(250 \mathrm{~mm} \times 4.6 \mathrm{~mm} ; 5 \mu \mathrm{m})$ at a temperature of $40{ }^{\circ} \mathrm{C}$. The fingerprints of phenolic acids were detected with a UV detector at $280 \mathrm{~nm}$. The commercial standard of protocatechuic acid (Sigma-Aldrich, Singapore) and vanillic acid (Sigma-Aldrich, Singapore) were designed for fingerprint identification.

\subsection{Statistical Analysis}

Data were expressed as the mean \pm SD. The paired Student $t$-test and one-way ANOVA followed by Turkey's test were used for the determination of the difference between the groups and the control. Significance was considered at $p \leq 0.05$.

\section{Results}

\subsection{Antioxidant Activity, Phenolic Content, and Mushroom Tyrosinase Inhibition of Germinated Riceberry Rice Extract}

Antioxidants are accepted for use in improving hyperpigmentation. In this study, the germination of riceberry rice promoted the antioxidant activity in all in vitro tests, while total phenolic content was not significantly different (Table 2). In addition, germinated riceberry rice extract efficiently inhibited tyrosinase, the key melanogenic enzyme, more than twice as effectively when compared with the an ungerminated sample, suggesting the potential of germinated riceberry rice for hyperpigmentation control.

Table 2. Antioxidant capacity, total phenolic content, and mushroom tyrosinase activity.

\begin{tabular}{|c|c|c|c|c|c|}
\hline \multirow[t]{2}{*}{ Conditions } & \multicolumn{3}{|c|}{ Antioxidant Capacity } & \multirow{2}{*}{$\begin{array}{c}\text { Total Phenolic } \\
\text { Content } \\
\text { Folin-Denis (mg } \\
\text { Gallic Acid } \\
\text { Equivalent/g } \\
\text { Sample) }\end{array}$} & \multirow{2}{*}{$\begin{array}{c}\text { Mushroom } \\
\text { Tyrosinase } \\
\text { Activity }\end{array}$} \\
\hline & $\begin{array}{c}\text { ABTS (mg } \\
\text { Trolox } \\
\text { Equivalent/g } \\
\text { Sample) }\end{array}$ & $\begin{array}{c}\text { DPPH (mg Vit } \\
\text { C Equivalent/g } \\
\text { Sample) }\end{array}$ & $\begin{array}{c}\text { FRAP (M } \\
\text { FeSO }{ }_{4} \cdot 7 \mathrm{H}_{2} \mathrm{O} \\
\text { Equivalent/g } \\
\text { Sample) }\end{array}$ & & \\
\hline Ungerminated & $1.37 \pm 0.02$ & $0.09 \pm 0.01$ & $3.05 \pm 0.01$ & $1.28 \pm 0.01$ & $123.26 \pm 3.21$ \\
\hline Germinated & $2.08 \pm 0.04^{* *}$ & $0.14 \pm 0.01 *$ & $3.29 \pm 0.05 *$ & $1.27 \pm 0.01$ & $60.08 \pm 4.24^{* *}$ \\
\hline
\end{tabular}

\subsection{Inhibitory Effect on Tyrosinase-Related Melanogenesis of Germinated Riceberry Rice Extract Treated B16 Cells}

The effects of germinated riceberry rice extract on tyrosinase-related melanin inhibition were then investigated at the cellular level using B16 cells. Firstly, the cytotoxic effect of the rice extracts was determined and showed no cytotoxicity at the concentrations of $10-40 \mathrm{mg} / \mathrm{mL}$ (Figure 1A,B). At non-toxic concentrations of 20 and $40 \mathrm{mg} / \mathrm{mL}$, germinated riceberry rice extract significantly inhibited cellular tyrosinase activity compared to ungerminated to $84 \pm 5.499 \%(p=0.026)$ and $67 \pm 3.147 \%$ $(p<0.001)$, respectively, when compared with untreated cells $(100 \%)$ (Figure $1 \mathrm{C})$. The result was interrelated with the melanin inhibition. Germinated riceberry rice extract also provided greater activity for cellular melanin inhibition than ungerminated riceberry rice by significantly reducing the melanin content to $80 \pm 5.718 \%(p=0.05)$ and $69 \pm 3.512 \%(p<0.001)$, respectively, when compared with untreated cells (100\%) (Figure 1D). 

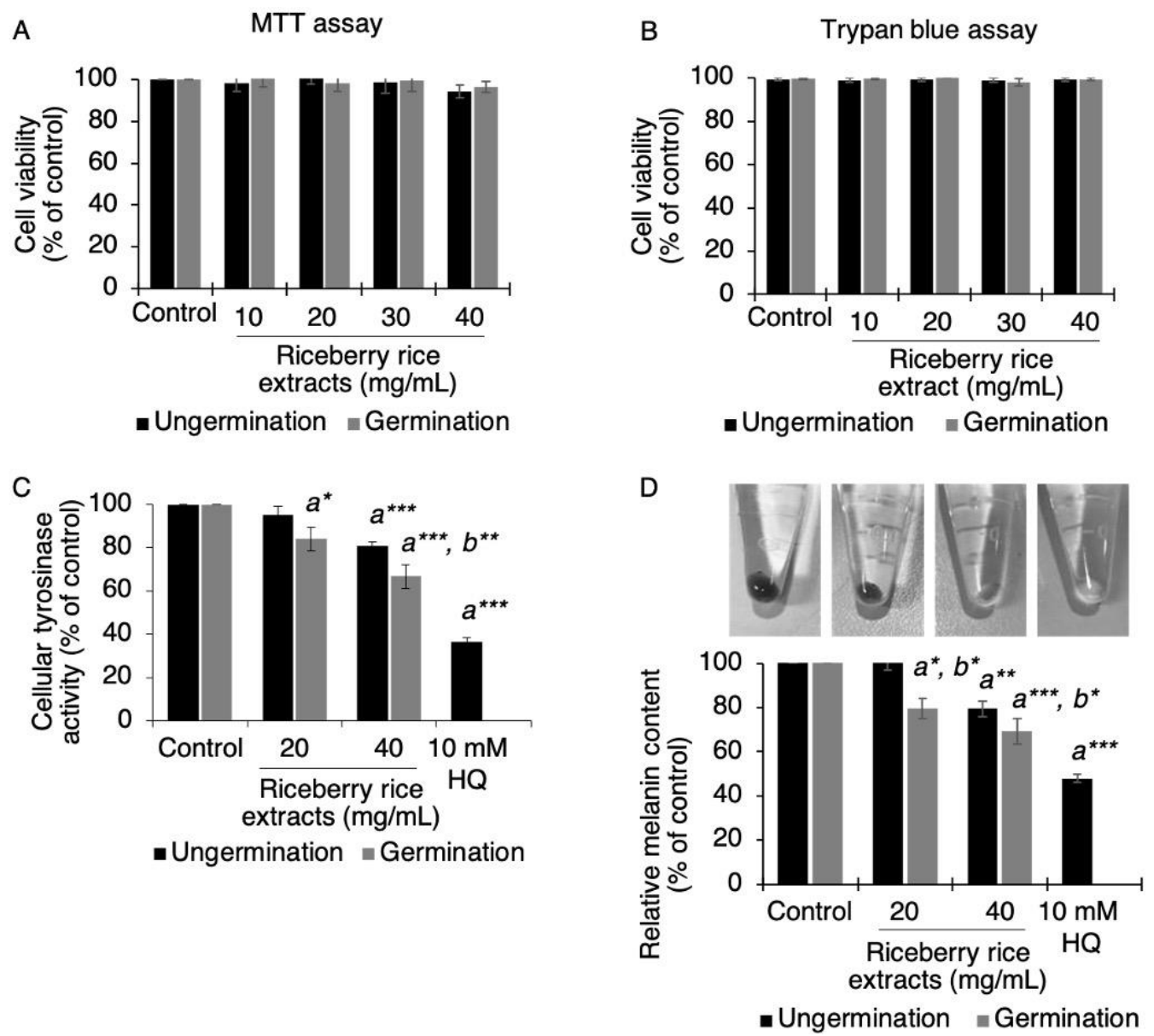

Figure 1. Effects of germinated riceberry rice extract on cellular tyrosinase and total melanin content in B16 cells. B16 cells were treated with ungerminated and germinated riceberry rice extracts at concentrations of 10,20,30, and $40 \mathrm{mg} / \mathrm{mL}$ and then tested for cytotoxicity by the MTT assay (A) and the trypan blue assay (B). Non-cytotoxic doses at 20 and $40 \mathrm{mg} / \mathrm{mL}$ were used on B16 cells for cellular tyrosinase activity $(\mathbf{C})$ and melanin content $(\mathbf{D})$. All results were expressed as the mean \pm SD by comparing with $100 \%$ of untreated cells. Ten millimolar of hydroquinone (HQ) was used as a positive control. ${ }^{*}{ }^{* *}, * * *$ Statistical significance at $p<0.05, p<0.01$, and $p<0.001$ and ${ }^{a, b}$ versus untreated cells and the ungerminated riceberry rice treatment group, respectively. Results from triplicate assays of two independent experiments.

\subsection{Melanin Pigmentation of B16 Cells Treated with Germinated Riceberry Rice Extract}

Cellular melanin content is relatively affected by the number of pigmented cells. In this study, the number of melanin containing B16 cells was investigated by using Fontana-Masson staining (Figure 2A-D). Treatment with germinated riceberry rice extract at the concentration of $40 \mathrm{mg} / \mathrm{mL}$ significantly reduced the number of melanin containing cells to $133 \pm 7.789$ cells/total 1000 cells when compared with the untreated cells ( $230 \pm 12.710$ cells/total 1000 cells). Additionally, the morphological appearance of B16 cells treated with germinated riceberry rice was also affected at the concentration of $20 \mathrm{mg} / \mathrm{mL}$ of treatment. Thus, the morphology of differenced B16 cells was then specifically investigated. 


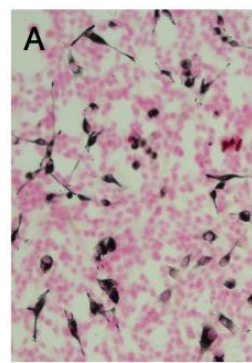

Untreated cells

E

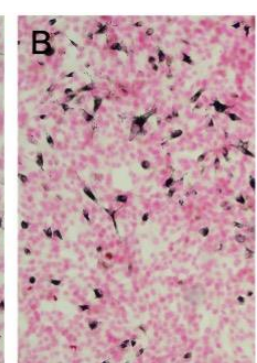

20

Germinated riceberry rice extract $(\mathrm{mg} / \mathrm{mL})$

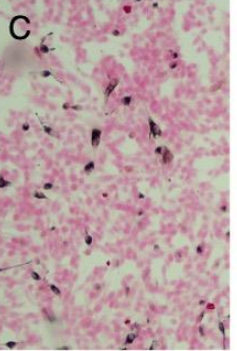

40

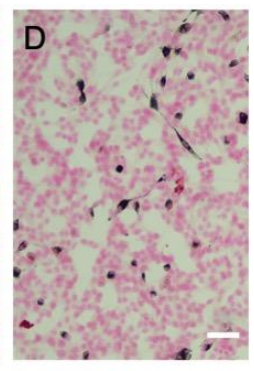

$10 \mathrm{mM}$

$\mathrm{HQ}$

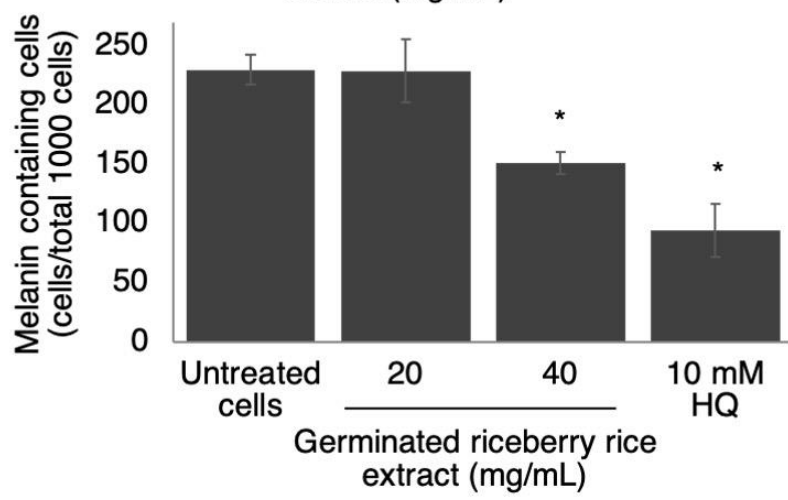

Figure 2. Effect of germinated riceberry rice extract on melanin pigmentation in B16 cells. Fontana-Masson's staining of B16 cells (A), B16 cells treated with germinated riceberry rice extract at 20 (B) and $40 \mathrm{mg} / \mathrm{mL}(\mathbf{C})$, and $10 \mathrm{mM}$ hydroquinone (HQ) (D). Melanin containing cells were counted by observing a total of 1000 cells under a light microscope at $100 \times$ magnification. Results were expressed as the mean \pm SD from triplicate samples from two independent experiments (E). * Statistical significances at $p<0.001$ when compared with untreated cells. Scale bar $=100 \mu \mathrm{m}$.

\subsection{Morphological Appearance of B16 Cells Treated with Germinated Riceberry Rice Extract}

The morphological appearance of differentiated B16 cells is associated with their cellular melanin accumulation. In this study, the morphology of differentiated B16 cells was scored as $1+, 2+, 3+$, and $4+$ (Figure 3A-D). Germinated riceberry rice extract reduced the population of high score differentiated B16 cells to have a lower score in a dose dependent manner (Figure 3E). At $20 \mathrm{mg} / \mathrm{mL}$ of treatment, the number of $4+$ differentiated B16 cells was significantly suppressed to $10 \pm 2.05$ cells/total 100 melanin containing cells when compared with untreated cells ( $14 \pm 1.63$ cells/total 100 melanin containing cells) $(p=0.049)$. The effect was shown more clearly at $40 \mathrm{mg} / \mathrm{mL}$ of treatment. The number of $3+$ and $4+$ differentiated B16 cells was significantly suppressed to $3 \pm 1.25$ and $2 \pm 0.47$ cells/total 100 melanin containing cells, respectively, when compared with untreated cells $(23 \pm 1.41$ and $14 \pm 1.63$ cells/total 100 melanin containing cells, respectively) $(p<0.001)$. The results demonstrated that germinated riceberry rice extract not only reduced melanin biosynthesis, but also affected the morphological appearance associated with melanocyte differentiation. 


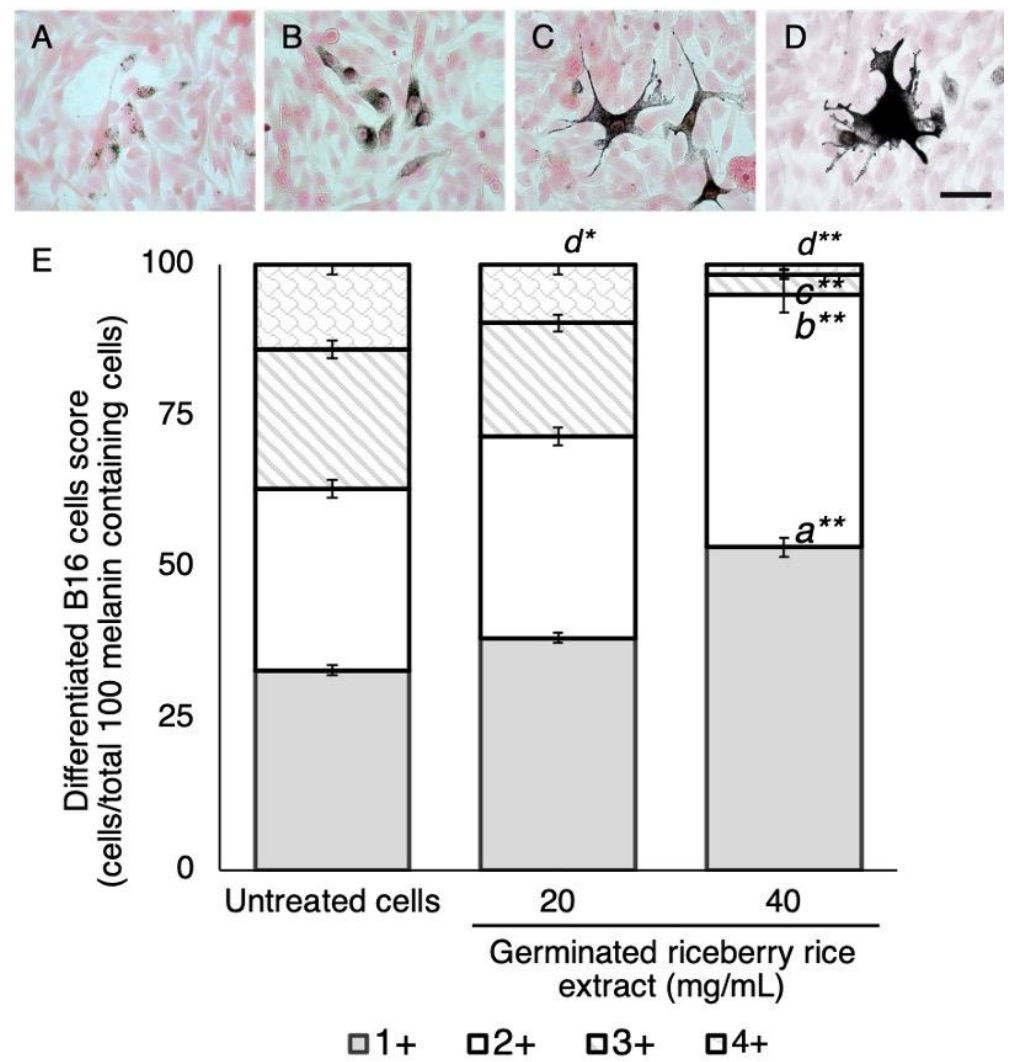

Figure 3. Effect of germinated riceberry rice extract on the morphological appearance of B16 cells. Differentiated B16 cells were scored as $1+(\mathbf{A}), 2+(\mathbf{B}), 3+(\mathbf{C})$, and $4+(\mathbf{D})$. Scoring was conducted by observing a total of 100 melanin containing cells under a light microscope at $100 \times$ magnification. Results were expressed as the mean \pm SD from triplicate samples from two blinded independent experiments (E). ${ }^{*} * *$ Statistical significances at $p<0.05$ and $p<0.001$ and ${ }^{a, b, c, d}$ versus a score of $1+$, $2+, 3+$, and $4+$ of untreated cells, respectively. Scale bar $=50 \mu \mathrm{m}$.

\subsection{Melanin Excretion and Cellular Oxidants of B16 Cells Treated with Germinated Riceberry Rice Extract}

Melanin excretion is a spontaneous characteristic of differentiated B16 cells. Likewise, the treatment of B16 cells with germinated riceberry rice extract at the concentrations of 20 and $40 \mathrm{mg} / \mathrm{mL}$ significantly inhibited the melanin excretion in a dose dependent manner to $72 \pm 9.87 \%$ $(p=0.001)$ and $45 \pm 4.15 \%(p<0.001)$, respectively, when compared with untreated cells $(100 \%)$ (Figure 4A,B).

The high antioxidant property of germinated riceberry rice extract was a target of tyrosinase-related melanogenesis inhibition. In this study, the cellular oxidants in B16 cells were then elucidated (Figure 4C). The results showed that germinated riceberry rice extract at the concentrations of 20 and $40 \mathrm{mg} / \mathrm{mL}$ significantly reduced cellular oxidants in B16 cells to $73 \pm 2.105 \%(p<0.001)$ and $54 \pm 0.963 \%(p<0.001)$, respectively, when compared with untreated cells $(100 \%)$. 
A

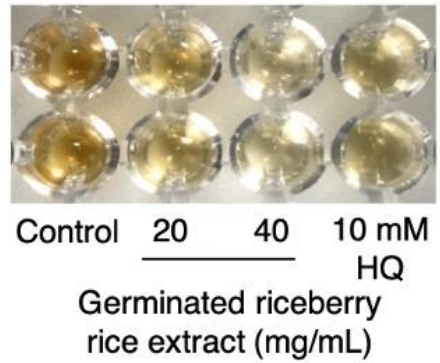

rice extract $(\mathrm{mg} / \mathrm{mL})$
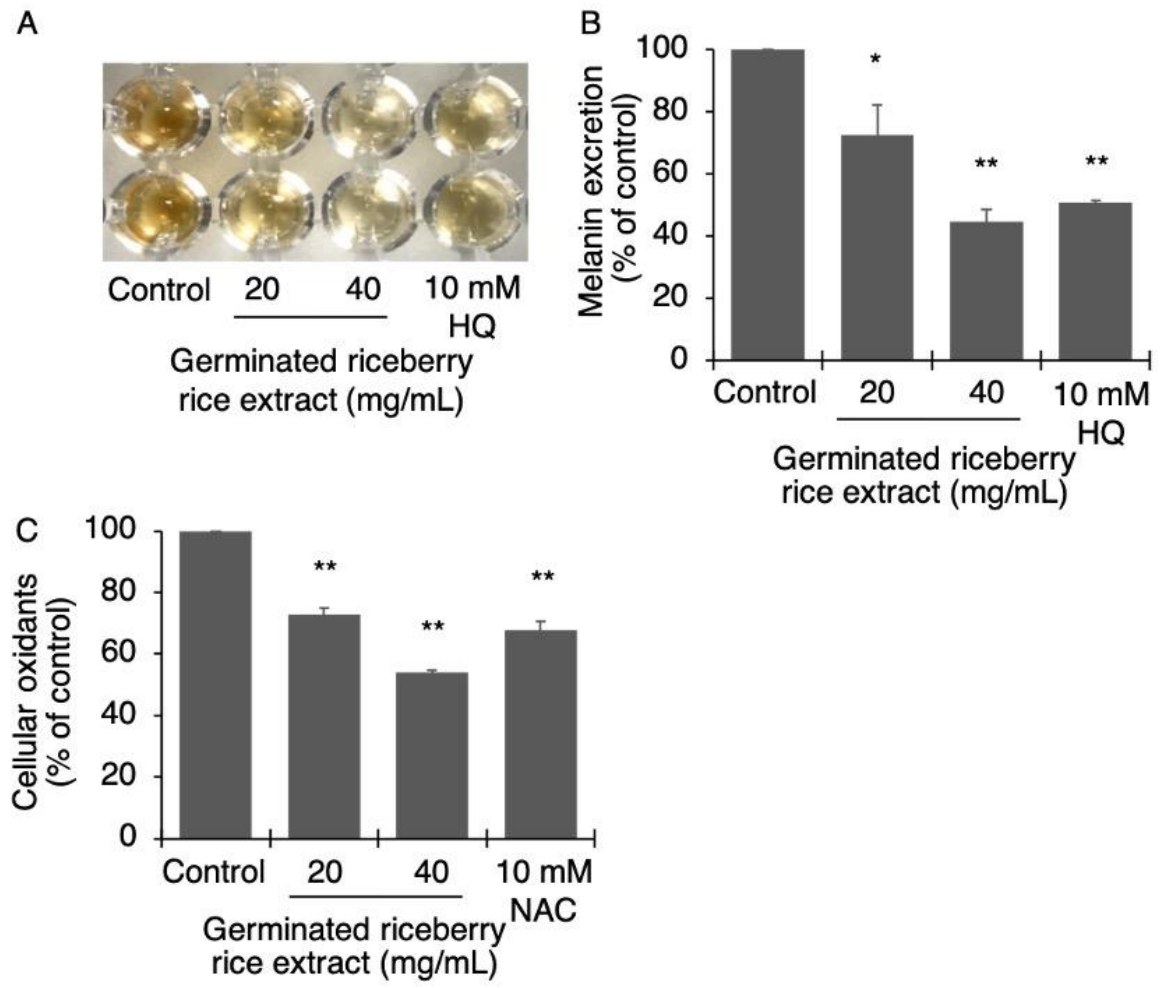

Figure 4. Effect of germinated riceberry rice extract on melanin excretion and cellular oxidants. B16 cells were treated with germinated riceberry rice extract at 20 and $40 \mathrm{mg} / \mathrm{mL}$. The melanin excretion was optically determined in a culture medium (A). Results were expressed in a bar graph (B) as the percentage of melanin excretion by comparing the mean \pm SD with $100 \%$ of untreated cells. Cellular oxidants were also determined (C). Ten micromolar hydroquinone (HQ) and N-acetylcysteine (NAC) were used as positive results for tyrosinase inhibition and antioxidants, respectively. ${ }^{* *}$ Statistical significances at $p<0.01$ and $p<0.001$, respectively, when compared with untreated cells. Results from triplicate assays of two independent experiments.

\subsection{Phytophenolics Fingerprints of Germinated Riceberry Rice Extract}

Germinated riceberry rice extract had high antioxidants and also showed high potency for anti-melanogenesis. The inhibition was associated with tyrosinase activity and cellular oxidants. Thus, the predominant phytochemicals in germinated riceberry rice extract were then identified with a comparison to ungerminated riceberry rice extract (Figure 5A,B). The results showed that two increasingly predominant phenolic compounds were presented in germinated riceberry rice extract and displayed the percentage of Areas 1 and 2 at $3.87 \%$ and $2.20 \%$, respectively, when compared with the total area. Meanwhile, the percentages of Areas 1 and 2 of ungerminated riceberry rice were $2.20 \%$ and $0.87 \%$, respectively, when compared with the total area. Then, the two increasingly dominant peaks of 1 and 2 were identified compared with the standards as protocatechuic acid and vanillic acid, respectively. 
A

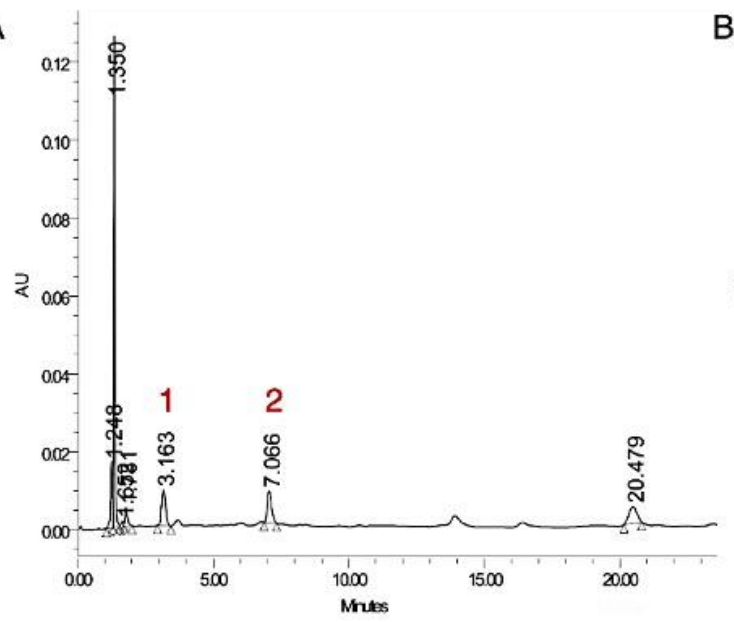

C

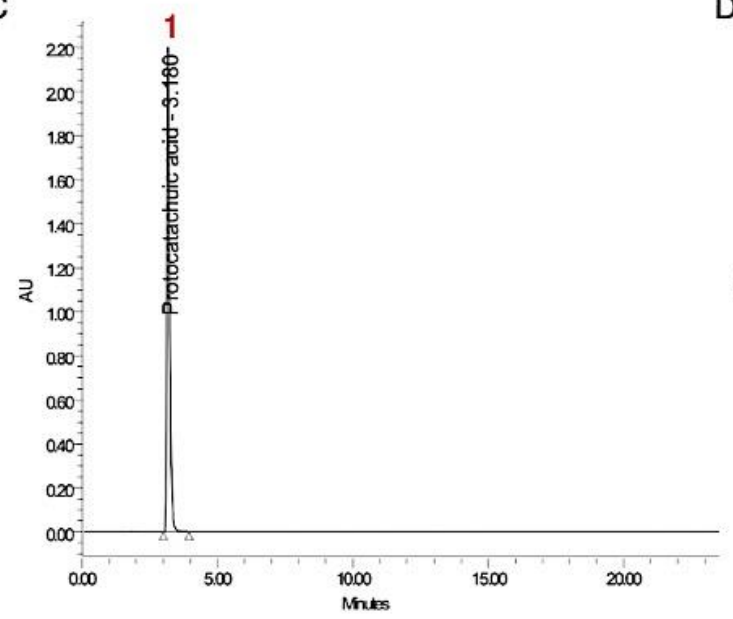

D
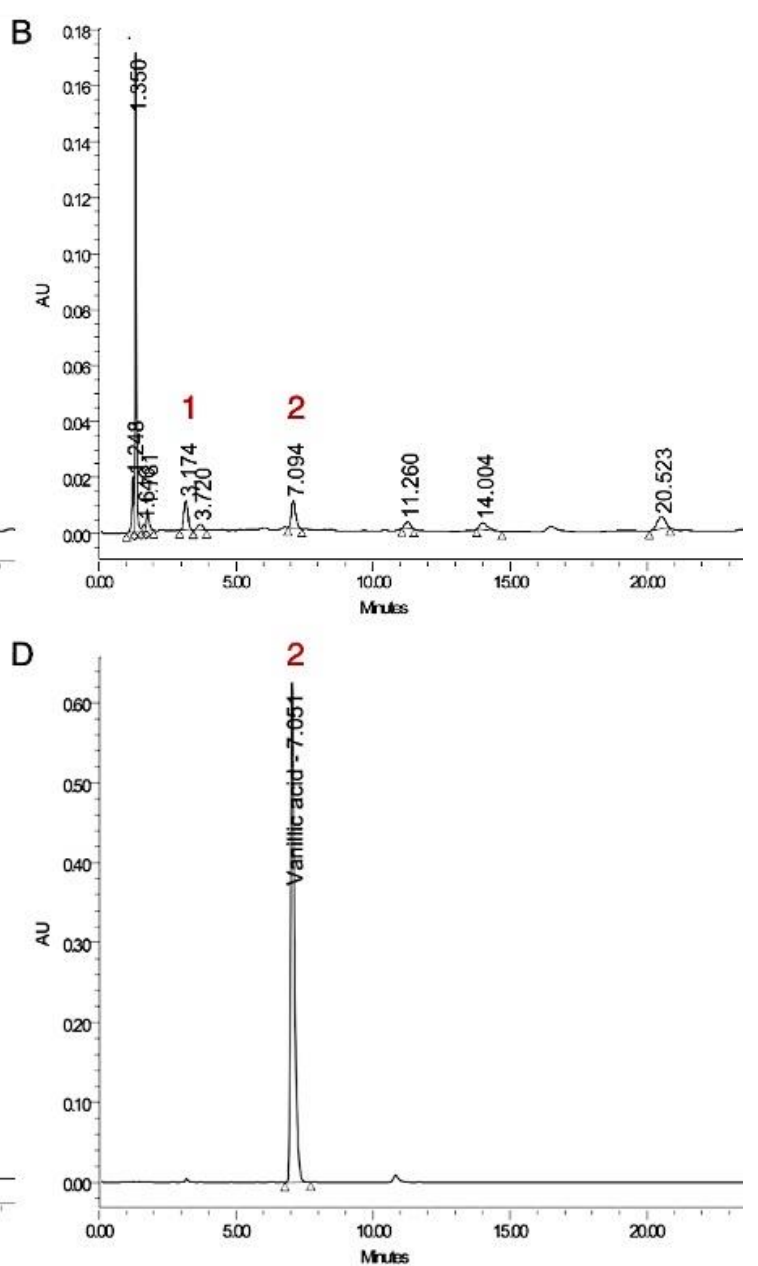

Figure 5. The HPLC chromatogram of ungerminated riceberry rice extract (A), germinated riceberry rice extract $(\mathbf{B})$, standards 1: protocatechuic acid (C) and 2: vanillic acid (D).

\section{Discussion}

The germination of riceberry rice promoted its antioxidants, while the phenolic contents were similar. As presented in a previous study, the short-term germination of the grain slightly altered the total phenolic content, but dynamically changed the phenolic profiles [26]. It is well known that tyrosinase enzyme plays a legitimate role in melanogenesis and can be modulated by antioxidants $[8,27]$. In this study, germinated riceberry rice extract had a strong inhibitory effect on tyrosinase-related melanogenesis and also affected the morphological appearance of B16 cells by reducing cell size, cellular melanin distribution, and dendriticity. In a previously study, the dendritic morphology was established as a hallmark of melanocyte differentiation-associated tyrosinase expression. It is also known to be the preceding process for melanin translocation $[27,28]$. In agreement with this study, germinated riceberry extract reduced the melanin excretion of B16 cells. In addition, cellular oxidative stress is recognized as a cause of hyperpigmentation and also used as a target for pigmentation control [29-31]. Concerning this study, germinated riceberry rice extract not only showed antioxidant activity in test tubes, but also reduced cellular oxidants in B16 cells. Furthermore, two dominant phenolic compounds were identified from germinated riceberry rice extract as protocatechuic acid and vanillic acid, which were previously established as an antioxidant and tyrosinase inhibitor [5,32]. These findings demonstrated that the short-term germination of riceberry rice promoted protocatechuic acid and vanillic acid, which may inhibit melanogenesis through the role of cellular oxidant-related tyrosinase activity. The extract also reduced cell differentiation-associated melanin excretion and showed potential for hyperpigmentation control. 


\section{Conclusions}

These results demonstrated the potential of short-term germinated riceberry rice extract as a new source of antioxidants and tyrosinase inhibitors. The extract also effectively reduced the melanin production effectively by interfering with the differentiation of melanin producing cells. Two targeted phenolic compounds, protocatechuic acid and vanillic acid, which have been recognized as tyrosinase inhibitors, were dominantly promoted under this germinating condition.

Author Contributions: Conceptualization, T.R. and P.S.; methodology, T.R.; software, T.R.; validation, T.R., P.S., and S.O.; formal analysis, T.R.; investigation, T.R.; resources, P.S. and S.O.; data curation, T.R.; writing, original draft preparation, T.R.; writing, review and editing, P.S.; visualization, P.S.; supervision, P.S. and S.O.; project administration, P.S.; funding acquisition, P.S. All authors read and agreed to the published version of the manuscript.

Funding: This research is financially supported by the Thailand Research Fund (Grant No. PHD 59I0038) and co-funded by Advanced Health Innovation Co., Ltd.

Acknowledgments: The authors also acknowledge the Department of Pathobiology, Faculty of Science, Mahidol University, Thailand, for the academic support.

Conflicts of Interest: The authors declare no conflict of interest.

\section{References}

1. Halder, R.M.; Nandedkar, M.A.; Neal, K.W. Pigmentary Disorders in Ethnic Skin. Dermatol. Clin. 2003, 21, 617-628. [CrossRef]

2. Oiso, N.; Tatebayashi, M.; Hoshiyama, Y.; Kawada, A. Allergic Contact Dermatitis Caused by Arbutin and Dipotassium Glycyrrhizate in Skin-Lightening Products. Contact Derm. 2017, 77, 51-53. [CrossRef] [PubMed]

3. Matsuo, Y.; Ito, A.; Masui, Y.; Ito, M. A Case of Allergic Contact Dermatitis Caused by Arbutin. Contact Derm. 2015, 72, 404-405. [CrossRef] [PubMed]

4. Truong, X.T.; Park, S.H.; Lee, Y.G.; Jeong, H.Y.; Moon, J.H.; Jeon, T.I. Protocatechuic Acid from Pear Inhibits Melanogenesis in Melanoma Cells. Int. J. Mol. Sci. 2017, 18, 1809. [CrossRef] [PubMed]

5. An, S.M.; Koh, J.S.; Boo, Y.C. p-Coumaric Acid Not Only Inhibits Human Tyrosinase Activity In Vitro but Also Melanogenesis in Cells Exposed to UVB. Phytother. Res. 2010, 24, 1175-1180.

6. Jo, H.; Choi, M.; Sim, J.; Viji, M.; Li, S.; Lee, Y.H.; Kim, Y.; Seo, S.Y.; Zhou, Y.; Lee, K.; et al. Synthesis and Biological Evaluation of Caffeic Acid Derivatives as Potent Inhibitors of Alpha-MSH-Stimulated Melanogenesis. Bioorg. Med. Chem. Lett. 2017, 27, 3374-3377. [CrossRef]

7. Li, H.R.; Habasi, M.; Xie, L.Z.; Aisa, H.A. Effect of Chlorogenic Acid on Melanogenesis of B16 Melanoma Cells. Molecules 2014, 19, 12940-12948. [CrossRef]

8. Im, K.H.; Baek, S.A.; Choi, J.; Lee, T.S. Antioxidant, Anti-Melanogenic and Anti-Wrinkle Effects of Phellinus vaninii. Mycobiology 2019, 47, 494-505. [CrossRef]

9. Ding, Y.; Jiratchayamaethasakul, C.; Kim, J.; Kim, E.A.; Heo, S.J.; Lee, S.H. Antioxidant and Anti-Melanogenic Activities of Ultrasonic Extract from Stichopus Japonicus. Asian Pac. J. Trop. Biomed. 2020, 10, 33-41.

10. Leardkamolkarn, V.; Thongthep, W.; Suttiarporn, P.; Kongkachuichai, R.; Wongpornchai, S.; Wanavijitr, A. Chemopreventive Properties of The Bran Extracted from A Newly-Developed Thai Rice: The Riceberry. Food Chem. 2011, 125, 978-985. [CrossRef]

11. Min, B.; McClung, A.M.; Chen, M.H. Phytochemicals and Antioxidant Capacities in Rice Brans of Different Color. J. Food Sci. 2011, 76, C117-C126. [CrossRef]

12. Tian, S.; Nakamura, K.; Kayahara, H. Analysis of Phenolic Compounds in White Rice, Brown Rice, and GerminatedBrown Rice. J. Agric. Food Chem. 2004, 52, 4808-4813. [CrossRef]

13. Cho, D.H.; Lim, S.T. Changes in Phenolic Acid Composition and Associated Enzyme Activity in Shoot and Kernel Fractions of Brown Rice During Germination. Food Chem. 2018, 256, 163-170. [CrossRef]

14. Abd Razak, D.L.; Abd Rashid, N.Y.; Jamaluddin, A.; Sharifudin, S.A.; Long, K. Enhancement of Phenolic Acid Content and Antioxidant Activity of Rice Bran Fermented with Rhizopus Oligosporus and Monascus Purpureus. Biocatal. Agric. Biotechnol. 2015, 4, 33-38. [CrossRef] 
15. Webber, D.M.; Hettiarachchy, N.S.; Li, R.; Horax, R.; Theivendran, S. Phenolic Profile and Antioxidant Activity of Extracts Prepared from Fermented Heat-Stabilized Defatted Rice Bran. J. Food Sci. 2014, 79, H2383-H2391. [CrossRef]

16. Aimvijarn, P.; Palipoch, S.; Okada, S.; Suwannalert, P. Thai Water Lily Extract Induces B16 Melanoma Cell Apoptosis and Inhibits Cellular Invasion Through the Role of Cellular Oxidants. Asian Pac. J. Cancer Prev. APJCP 2018, 19, 149-153.

17. Brand, W.W.; Cuvelier, M.E.; Berset, C. Use of a Free Radical Method to Evaluate Antioxidant Activity. LWT Food Sci. Technol. 1995, 28, 25-30. [CrossRef]

18. Benzie, I.F.; Strain, J.J. The Ferric Reducing Ability of Plasma (FRAP) as a Measure of "Antioxidant Power": The FRAP Assay. Anal. Biochem. 1996, 239, 70-76. [CrossRef]

19. Ashraf, Z.; Rafiq, M.; Seo, S.Y.; Babar, M.M.; Zaidi, N.U. Synthesis, Kinetic Mechanism and Docking Studies of Vanillin Derivatives as Inhibitors of Mushroom Tyrosinase. Bioorg. Med. Chem. 2015, 23, 5870-5880. [CrossRef]

20. Hansen, M.B.; Nielsen, S.E.; Berg, K. Re-Examination and Further Development of a Precise and Rapid Dye Method for Measuring Cell Growth/Cell Kill. J. Immunol. Methods 1989, 119, 203-210. [CrossRef]

21. Soltanian, S.; Sheikhbahaei, M.; Mohamadi, N. Cytotoxicity Evaluation of Methanol Extracts of Some Medicinal Plants on P19 Embryonal Carcinoma Cells. J. Appl. Pharm. 2017, 7, 142-149.

22. Hsu, K.D.; Chen, H.J.; Wang, C.S.; Lum, C.C.; Wu, S.P.; Lin, S.P.; Cheng, K.C. Extract of Ganoderma formosanum Mycelium as a Highly Potent Tyrosinase Inhibitor. Sci. Rep. 2016, 6, 32854. [CrossRef]

23. Chang, T.S.; Lin, V.C. Melanogenesis Inhibitory Activity of Two Generic Drugs: Cinnarizine and Trazodone in Mouse B16 Melanoma Cells. Int. J. Mol. 2011, 12, 8787-8796. [CrossRef] [PubMed]

24. Lee, M.H.; Lin, Y.P.; Hsu, F.L.; Zhan, G.R.; Yen, K.Y. Bioactive Constituents of Spatholobus Suberectus in Regulating Tyrosinase-Related Proteins and mRNA in HEMn Cells. Phytochemistry 2006, 67, 1262-1270. [CrossRef]

25. Pengkumsri, N.; Chaiyasut, C.; Saenjum, C.; Sirilun, S.; Peerajan, S.; Suwannalert, P.; Sirisattha, S.; Sivamaruthi, S.S. Physicochemical and Antioxidative Properties of Black, Brown and Red Rice Varieties of Northern Thailand. Food Sci. Technol. 2015, 35, 331-338. [CrossRef]

26. Xu, J.G.; Tian, C.R.; Hu, Q.P.; Luo, J.Y.; Wang, X.D.; Tian, X.D. Dynamic Changes in Phenolic Compounds and Antioxidant Activity in Oats (Avena nuda L.) During Steeping and Germination. J. Agric. Food Chem. 2009, 57, 10392-10398. [CrossRef]

27. Bertolotto, C.; Abbe, P.; Hemesath, T.J.; Bille, K.; Fisher, D.E.; Ortonne, J.P.; Ballotti, R. Microphthalmia Gene Product as a Signal Transducer in cAMP-Induced Differentiation of Melanocytes. J. Cell Biol. 1998, 142, 827-835. [CrossRef]

28. Boissy, R.E. Melanosome Transfer to and Translocation in The Keratinocyte. Exp. Dermatol. 2003, 12, 5-12. [CrossRef]

29. Galato, D.; Ckless, K.; Susin, M.F.; Giacomelli, C.; Ribeiro-do-Valle, R.M.; Spinelli, A. Antioxidant Capacity of Phenolic and Related Compounds: Correlation Among Electrochemical, Visible Spectroscopy Methods and Structure-Antioxidant Activity. Redox Rep. 2001, 6, 243-250. [CrossRef]

30. Emerit, I. Free Radicals and Aging of The Skin. In Free Radicals and Aging. EXS; Emerit, I., Chance, B., Eds.; Birkhäuser Basel: Basel, Switzerland, 1992; Volume 62, pp. 328-341.

31. Ding, H.Y.; Chou, T.H.; Lin, R.J.; Chan, L.P.; Wang, G.H.; Liang, C.H. Antioxidant and Antimelanogenic Behaviors of Paeonia Suffruticosa. Plant Foods Hum. Nutr. 2011, 66, 275-284. [CrossRef]

32. Liu, J.; Xu, X.; Jiang, R.; Sun, L.; Zhao, D. Vanillic Acid in Panax Ginseng Root Extract Inhibits Melanogenesis in B16F10 Cells Via Inhibition of the NO/PKG Signaling Pathway. Biosci. Biotechnol. Biochem. 2019, 83, 1205-1215. [CrossRef] [PubMed]

(C) 2020 by the authors. Licensee MDPI, Basel, Switzerland. This article is an open access article distributed under the terms and conditions of the Creative Commons Attribution (CC BY) license (http://creativecommons.org/licenses/by/4.0/). 